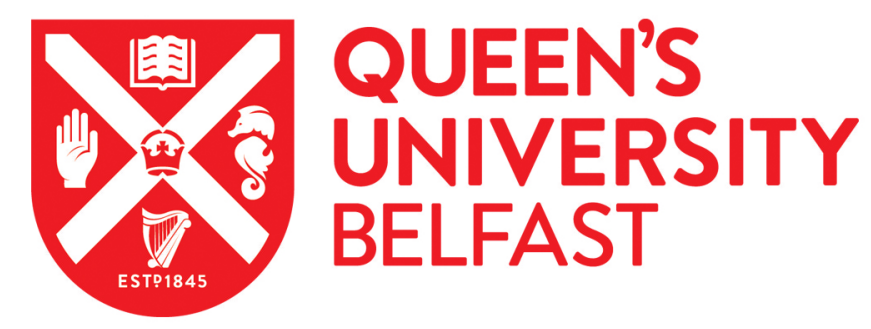

\title{
A modified glass bead compartment cultivation system for studies on nutrient and trace metal uptake by arbuscular mycorrhiza
}

Chen, B. D., Christie, P., \& Li, X. L. (2001). A modified glass bead compartment cultivation system for studies on nutrient and trace metal uptake by arbuscular mycorrhiza. Chemosphere, 42, 185-192.

Published in:

Chemosphere

Queen's University Belfast - Research Portal:

Link to publication record in Queen's University Belfast Research Portal

\section{General rights}

Copyright for the publications made accessible via the Queen's University Belfast Research Portal is retained by the author(s) and / or other copyright owners and it is a condition of accessing these publications that users recognise and abide by the legal requirements associated with these rights.

Take down policy

The Research Portal is Queen's institutional repository that provides access to Queen's research output. Every effort has been made to ensure that content in the Research Portal does not infringe any person's rights, or applicable UK laws. If you discover content in the Research Portal that you believe breaches copyright or violates any law, please contact openaccess@qub.ac.uk. 


\title{
A modified glass bead compartment cultivation system for studies on nutrient and trace metal uptake by arbuscular mycorrhiza
}

\author{
Baodong Chen ${ }^{\text {a }}$, Peter Christie ${ }^{\text {a,b }}$, Xiaolin $\mathrm{Li}^{\text {a,* }}$ \\ ${ }^{a}$ College of Agricultural Resources and Environmental Sciences, China Agricultural University, Beijing 100094, \\ People's Republic of China \\ ${ }^{\mathrm{b}}$ Department of Agricultural and Environmental Science, The Queen's University of Belfast, Newforge Lane, Belfast BT9 5PX, UK
}

\begin{abstract}
A modified glass bead compartment cultivation system is described in which glass beads continue to be used in the hyphal compartment but are replaced by coarse river sand in the compartments for host plant roots and mycorrhizal hyphae. Arbuscular mycorrhizal (AM) associations were established using two host plant species, maize (Zea mays L.) and red clover (Trifolium pratense L.) and two AM fungi, Glomus mosseae and G. versiforme. When the standard and modified cultivation systems were compared, the new method yielded much more fungal tissue in the hyphal compartment. Using G. versiforme as the fungal symbiont, up to $30 \mathrm{mg}$ of fungal dry matter (DM) was recovered from the hyphal compartment of mycorrhizal maize and about $6 \mathrm{mg}$ from red clover. Multi-element analysis was conducted on samples of host plant roots and shoots and on harvested fungal biomass. Concentrations of $\mathrm{P}, \mathrm{Cu}$ and $\mathrm{Zn}$ were much higher in the fungal biomass than in the roots or shoots of the host plants but fungal concentrations of $\mathrm{K}, \mathrm{Ca}, \mathrm{Mg}, \mathrm{Fe}$ and $\mathrm{Mn}$ were similar to or lower than those in the plants. There were also significant differences in nutrient concentrations between the two AM fungi and these may be related to differences in their proportions of extraradical mycelium to spores. The high affinity of the fungal mycelium for $\mathrm{Zn}$ was very striking and is discussed in relation to the potential use of arbuscular mycorrhiza in the phytoremediation of Zn-polluted soils. (c) 2000 Elsevier Science Ltd. All rights reserved.
\end{abstract}

Keywords: Arbuscular mycorrhiza; Glass bead cultivation; Heavy metals; Nutrient uptake

\section{Introduction}

There has been considerable interest in the potential use of arbuscular mycorrhiza in agricultural systems. Over the last few decades many experiments have demonstrated increased plant uptake of nutrients, especially relatively immobile elements such as $\mathrm{P}$ and $\mathrm{Zn}$, by mycorrhizal plants compared with non-mycorrhizal controls. Experiments have shown that the mycorrhizal

\footnotetext{
${ }^{*}$ Corresponding author.

E-mail address: lixl@mx.cei.gov.cn (X. Li).
}

effect can be explained by mechanisms such as enlargement of the absorbing area and volume of accessible soil, decreased soil $\mathrm{pH}$ near the fungal hyphae due to exudation of organic acids and other ions, a high affinity to $\mathrm{P}$ on the membranes of arbuscular mycorrhizal (AM) fungi and efficient hyphal transport in the form of polyphosphate, and utilisation by mycorrhiza of $\mathrm{P}$ sources that are unavailable to plant roots ( $\mathrm{Li}$ and $\mathrm{Cao}$, 1993; Smith and Read, 1997).

Because the axenic culture of AM fungi in the laboratory is still not feasible (Williams, 1994), many indirect studies have been conducted on the fungal symbionts. Techniques used include compartment box culture ( $\mathrm{Li}$ 
et al., 1991a,b,c) and axenic dual culture of the AM fungi with transformed root organ tissue (Mugnier and Mosse, 1987; Becard and Fortin, 1988; Becard and Piche, 1989, 1992). Although these methods have provided interesting results and new insights into the nature of the mycorrhizal symbiosis, there is still a need for more direct methods for the study of physiological and biochemical processes in AM fungi. More information is required on the fundamental biology of these fungi to make their widespread use in agriculture a realistic prospect.

Fundamental research on most microorganisms has depended on the production of pure cultures. However, the traditional method of producing AM fungal material for study is pot culture in which the fungi grow on the roots of host plants growing in pots of substrate such as sand or a mixture of soil and sand, and these methods provide material of low purity (Horn et al., 1993). Sterile spores derived from transformed root cultures can be of great value for specialised applications but establishment of the cultures is extremely tedious and difficult. Redecker et al. $(1995,1998)$ described for the first time a cultivation system for arbuscular mycorrhiza using glass beads. The key advantage is that the fungal materials can be easily separated from the cultivation media in adequate quantities for experimental study. Fungal materials derived from the glass bead system retain their natural microflora and at the same time exogenous contamination can be avoided. In addition to providing material for biochemical and molecular biology experiments, the cultivation system can also contribute to studies on nutrient and trace metal uptake via AM fungi. It is very convenient and efficient and therefore potentially useful for a broad range of studies.

In this paper, we report a modified glass bead cultivation system designed to further improve the efficiency of fungal biomass production. Two experiments are described that were conducted to study the partitioning of mineral nutrients and trace elements in the shoots and roots of mycorrhizal plants and in the associated extramatrical fungal mycelium. The results are discussed in terms of possible mechanisms of nutrient uptake by, and alleviation of, heavy metal toxicity to the host plant via the external hyphae.

\section{Materials and methods}

\subsection{Mycorrhiza inoculum}

Inoculum of the AM fungi Glomus mosseae (Nicol. \& Gerd.) Gerdemann \& Trappe and G. versiforme (Karsten) Berch comprised a sandy soil containing spores of the appropriate fungus and maize root fragments. The original inoculum was kindly provided by Professor Zhang of the Institute of Plant Nutrition and Fertilisers,
Beijing Academy of Agronomy and Forestry, and was propagated several times on maize plants grown in a sandy soil for ten weeks.

\subsection{Host plants}

Seeds of maize (Zea mays L.) and red clover (Trifolium repens $\mathrm{L}$.) were surface sterilised in a $10 \% \mathrm{v} / \mathrm{v}$ solution of hydrogen peroxide for $10 \mathrm{~min}$. They were pre-germinated overnight and were then ready for sowing.

\subsection{Cultivation media}

A sandy soil of low nutrient status was collected from Panggezhang village, Daxing County, Beijing and was passed through a $1 \mathrm{~mm}$ sieve. The soil had the following properties (DM, dry matter basis): $\mathrm{pH}$ (in water) 7.8 , $0.39 \%$ organic matter, $0.027 \%$ total N, $3.9 \mathrm{mg} \mathrm{kg}^{-1} 0.5 \mathrm{M}$ $\mathrm{NaHCO}_{3}$-extractable $\mathrm{P}$, and $60.4 \mathrm{mg} \mathrm{kg} \mathrm{m}^{-1} \mathrm{M}$ $\mathrm{NH}_{4} \mathrm{OAc}$-extractable $\mathrm{K}$. Trace metals extractable with $0.005 \mathrm{M}$ DTPA/ $/ 0.01 \mathrm{M} \mathrm{CaCl}_{2} / 0.1 \mathrm{M}$ TEA were $\mathrm{Cu} 0.80$, $\mathrm{Fe} 7.6$, Mn 3.6 and $\mathrm{Zn} 0.63 \mathrm{mg} \mathrm{kg}^{-1}$. Other materials used were sand $(<1 \mathrm{~mm})$, coarse river sand $(1-2 \mathrm{~mm})$ and glass beads $(0.8-1.2 \mathrm{~mm}$ diameter). The glass beads and coarse river sand were acid-washed, and all of the substrates were sterilised by autoclaving at $120^{\circ} \mathrm{C}$ for $2 \mathrm{~h}$ and then air-dried.

\subsection{Experiments}

Two experiments were conducted. In the first, the effects of different cultivation media on the efficiency of fungal biomass production were studied. The containers used for the cultivation system were boxes made of Plexiglas (Acrylic). Each container was separated into five compartments as shown in Fig. 1. The different pore sizes of the screens allowed partitioning of the containers into compartments that contained host plants (PC), roots and extramatrical hyphae (RC), or hyphae only (HC). Screens A and D had pores of $1 \mathrm{~mm}$, and B and C of $30 \mu \mathrm{m}$. The dimensions (in $\mathrm{cm}$ ) of the boxes used for growing maize were $(10 \times 15 \times(3+4+5+4+3))$, and those for red clover were $(8 \times 8 \times(2+3+4+3+2))$. Plant growth compartments 1 and 5 (PC) were filled with a 1:1 w/w mixture of sandy soil and sand. Root and hyphal growth compartments 2 and 4 (RC) were filled with coarse river sand or glass beads (depending on treatment) and the central hyphal compartment 3 (HC) contained glass beads. Water (or 1/4 strength Hoagland's solution when necessary but with $\mathrm{P}$ concentration reduced to $1 / 10$ ) was added every few days, but only to compartments 2 and 4 to minimise the risk of contamination from the outer compartments. After a plant growth period of about eight weeks, spores and hyphae that had developed between the glass beads in compartment 3 were recovered for study using a flotation 
(a)

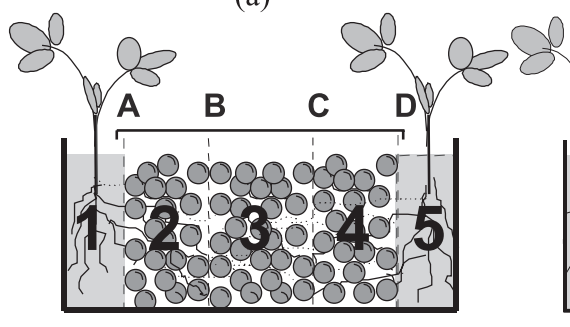

(b)

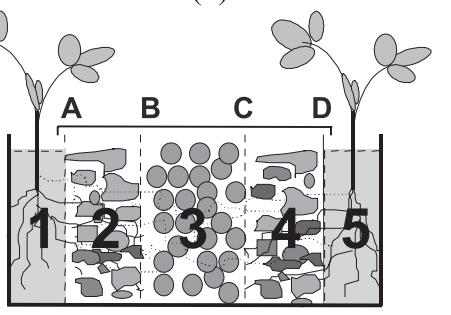

Fig. 1. Diagrammatic representation of the (a) unmodified and (b) modified glass bead compartment cultivation system. Compartments (numbered 1 to 5) are separated by nylon mesh screens (designated A to D). Hyphae are represented by broken lines and roots by solid lines. In (b), the compartments for roots and hyphae ( 2 and 4 ) contain coarse river sand instead of glass beads. For further details, see text.

technique. The glass beads and associated fungal materials were removed with a spoon, transferred to a beaker and stirred in distilled water. The glass beads sank rapidly and the fungal materials were decanted onto a 70 $\mu \mathrm{m}$ sieve. This procedure was repeated twice to obtain full recovery. There were two host plant species, two fungal symbionts, two different substrates in the hyphal compartment and four replicates, giving a total of 32 containers. The second experiment was designed to study the partitioning of nutrients in mycorrhizal plants. Three-compartment boxes were constructed by omitting compartments 4 and 5. Coarse river sand was the only substrate used in compartment 2. Thus, there were two host plants, two fungi and four replicates to give a total of 16 containers in this experiment.

Mycorrhiza inoculum (30 g for maize and $15 \mathrm{~g}$ for red clover) was mixed into the soil/sand mixture in PC compartments 1 and 5 before sowing. Five seeds of maize or about 50 seeds of clover were sown in each of the two plant growth compartments. The plants grew under a $25^{\circ} \mathrm{C} / 22^{\circ} \mathrm{C}$ temperature regime with a $14 \mathrm{~h}$ photoperiod at a light intensity of $250 \mu \mathrm{mol} \mathrm{m} \mathrm{m}^{-2} \mathrm{~s}^{-1}$ provided by supplementary illumination. In other respects the method followed Redecker et al. (1995).

At harvest the cultivation containers were dismantled and shoots, roots or fungal hyphae were recovered separately, oven dried and weighed. Fungal biomass from the central compartment was recovered on a $70 \mu \mathrm{m}$ sieve, oven dried at $50^{\circ} \mathrm{C}$ and weighed.

\subsection{Elemental analysis}

Oven dried plant shoots and roots were ground in a Pulverisette Model 14 stainless steel mill and dry ashed. Fungal biomass was dried as described above, weighed and dry ashed. The concentrations of $\mathrm{P}, \mathrm{K}, \mathrm{Ca}, \mathrm{Mg}, \mathrm{Fe}$, $\mathrm{Mn}, \mathrm{Cu}$ and $\mathrm{Zn}$ were determined using inductively coupled plasma - atomic emission spectroscopy (ICPAES). Data were tested by analysis of variance and means were compared by least significant difference (LSD) at the 5\% level.

\section{Results}

\subsection{First experiment}

Cultures of both $G$. mosseae and $G$. versiforme were established on both host plant species under our experimental conditions. At the end of the cultivation period relatively large amounts of fungal biomass were obtained (Fig. 2), especially of $G$. versiforme which produced numerous small spores (Fig 2 (a)). In contrast, G. mosseae formed relatively few sporocarps of diameter 0.1-0.3 $\mathrm{mm}$. When the root and hyphal compartments (RC) contained coarse river sand there was more root growth compared with the original method of using glass beads. More importantly, the modified method produced significantly larger amounts of fungal tissue (Table 1).

\subsection{Second experiment}

When maize was the host plant the concentrations of $\mathrm{P}, \mathrm{Cu}$ and $\mathrm{Zn}$ were higher in the fungal tissue than in the roots, and higher in the roots than in the shoots (Fig. 3). The accumulation of $\mathrm{Zn}$ in the fungal material was particularly notable, with concentrations of over $1200 \mathrm{mg}$ $\mathrm{kg}^{-1}$ in $G$. mosseae and over $600 \mathrm{mg} \mathrm{kg}^{-1}$ in G. versiforme. In contrast, concentrations of $\mathrm{K}, \mathrm{Mg}$ and $\mathrm{Mn}$ in the fungal structures were lower than in the plants, while $\mathrm{Fe}$ and $\mathrm{Ca}$ were present in similar concentrations in the fungi and the host plant. Table 2 shows that the concentrations of most of the elements studied were significantly different in the two mycorrhizal fungi.

Only a small amount of fungal biomass could be recovered from the mycorrhizal red clover cultures, and the fungal material from the four replicate containers of each treatment was therefore bulked for chemical analysis. The data cannot therefore be analysed statistically. However, Table 3 shows that despite the comparatively low $\mathrm{P}$ concentration in the fungal structures, the data showed similar trends to those obtained from maize culture. 

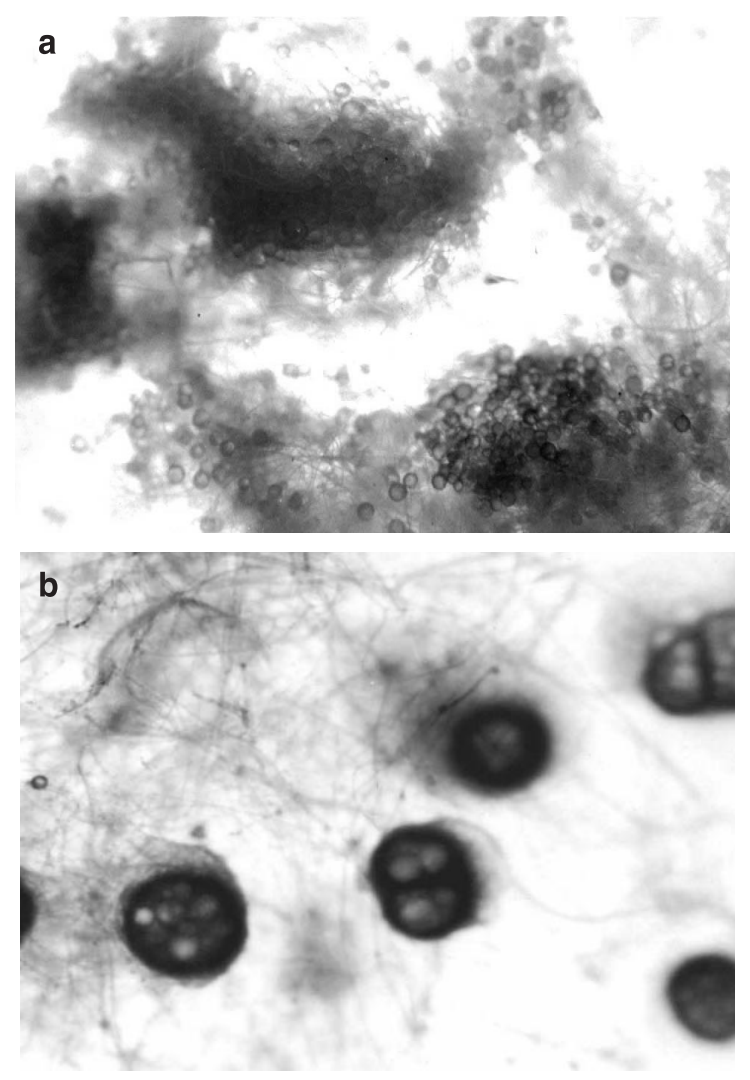

Fig. 2. Photomicrographs showing (a) spores and hyphae of Glomus versiforme $(\times 110)$ and $(b)$ sporocarps and hyphae of Glomus mosseae recovered from the hyphal compartment $(\times 200)$.

\section{Discussion}

One modification that was made to the original method was to use $30 \mu \mathrm{m}$ pore Nylon mesh instead of
$0.1 \mathrm{~mm}$ mesh to prevent root penetration into the hyphal compartment. This is important because the roots of some plant species, for example perennial ryegrass, can penetrate pores larger than $30 \mu \mathrm{m}$ (Rogers et al., this issue). A second modification was to replace the glass beads in the compartments for root and hyphal growth with coarse river sand. This resulted in higher yields of fungal structures in the central hyphal compartment, in which the use of glass beads was retained. River sand particles have much rougher surfaces and irregular shape than glass beads and the roots seem to adhere better to the particles. This leads to more extensive root growth. When the cultivation system was dismantled, a mat of roots could be seen to have formed on the two $30 \mu \mathrm{m}$ mesh barriers. As a result, a much larger biomass of fungal structures developed in the central hyphal compartment. In addition, the spaces between sand particles are relatively narrow and the particles have a strong tendency to retain water and thus maintain humidity. The resulting decline in water movement may also reduce the risk of contamination of the fungal materials by soil particles from the outermost plant growth compartments.

We have found that plants growing in the two outer compartments ( 1 and 5) of the same container often have very different yields. Moreover, we cannot determine from which side the fungal materials in the central compartment are derived. This is why a three-compartment box was adopted for the second experiment. The container system is very flexible, and boxes can be designed specifically for the special requirements of each experiment.

Our results indicate that fungal biomass production is determined primarily by fungal species. It was clear that spores (sporocarps) played an important role in biomass formation, and $G$. versiforme has a great capacity for sporulation and can produce a relatively large amount of fungal biomass. Root mass and root infection

Table 1

Effects of different substrate media on root distribution and efficiency of fungal biomass production in the cultivation system ${ }^{\mathrm{a}}$

\begin{tabular}{|c|c|c|c|c|c|c|}
\hline \multirow[t]{2}{*}{ Host plant } & \multirow[t]{2}{*}{ AM fungus } & \multirow[t]{2}{*}{ Substrate in RC } & \multicolumn{2}{|c|}{ Root mass (g) } & \multirow{2}{*}{$\begin{array}{l}\text { Ratio of dry root } \\
\text { mass (RC:PC) }\end{array}$} & \multirow{2}{*}{$\begin{array}{l}\text { Fungal biomass } \\
\text { in } \mathrm{HC}(\mathrm{mg})\end{array}$} \\
\hline & & & $\overline{\mathrm{PC}}$ & $\mathrm{RC}$ & & \\
\hline \multirow[t]{4}{*}{ Red clover } & \multirow[t]{2}{*}{ G. mosseae } & Glass beads & $1.90 \mathrm{a}^{\mathrm{b}}$ & $0.12 b$ & 0.063 & $\mathrm{ND}^{\mathrm{c}}$ \\
\hline & & River sand & $1.41 \mathrm{a}$ & $0.26 \mathrm{a}$ & 0.184 & 1.03 \\
\hline & \multirow[t]{2}{*}{ G. versiforme } & Glass beads & $1.76 \mathrm{a}$ & $0.09 b$ & 0.051 & $0.65 b$ \\
\hline & & River sand & $1.47 \mathrm{a}$ & $0.28 \mathrm{a}$ & 0.190 & $6.63 \mathrm{a}$ \\
\hline \multirow[t]{4}{*}{ Maize } & \multirow[t]{2}{*}{ G. mosseae } & Glass beads & $3.70 \mathrm{~b}$ & $0.60 \mathrm{~b}$ & 0.162 & $3.88 \mathrm{~b}$ \\
\hline & & River sand & $7.20 \mathrm{a}$ & $1.62 \mathrm{a}$ & 0.225 & $8.64 a$ \\
\hline & \multirow[t]{2}{*}{ G. versiforme } & Glass beads & $4.16 a$ & $0.64 b$ & 0.155 & $3.07 \mathrm{~b}$ \\
\hline & & River sand & $5.24 \mathrm{a}$ & $1.52 \mathrm{a}$ & 0.291 & $22.75 \mathrm{a}$ \\
\hline
\end{tabular}

\footnotetext{
${ }^{\text {a }}$ PC: plant compartments (1 and 5), RC: root + hyphae compartments (2 and 4), HC: hyphal compartment (3).

${ }^{\mathrm{b}}$ Means followed by the same letter are not significantly different by least significant difference at the $5 \%$ level.

${ }^{\mathrm{c}}$ Fungal tissue not detected.
} 


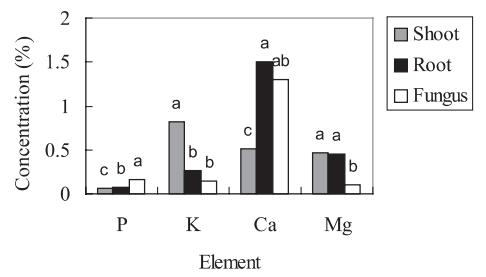

(a)

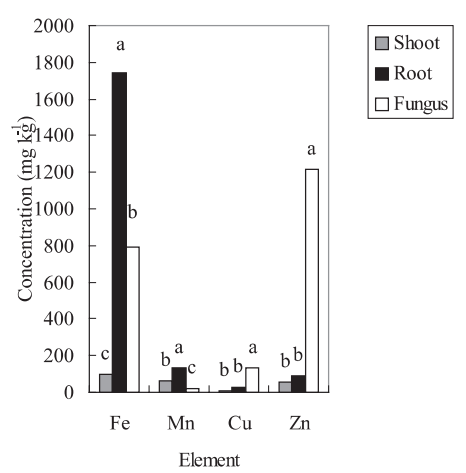

(c)

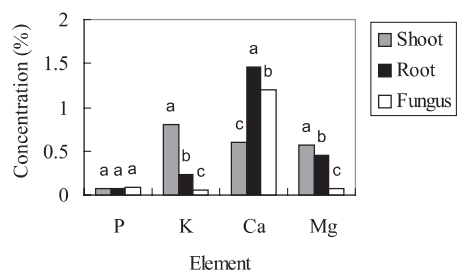

(b)

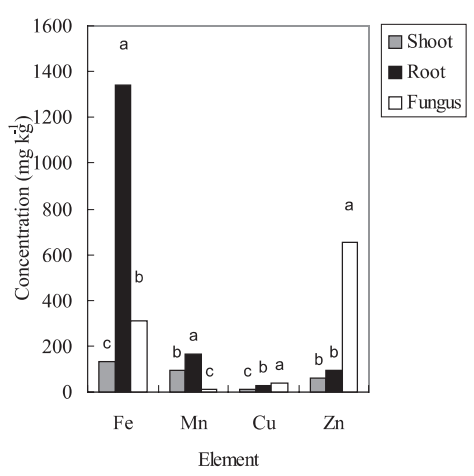

(d)

Fig. 3. Nutrient partitioning in mycorrhizal maize colonised by Glomus mosseae (a and c) or Glomus versiforme (b and d). For each element, letters above the bars indicate differences between means by least significant difference at the $5 \%$ level.

rate also has a substantial influence on fungal biomass production. Maize has a large root system and produces copious exudates. Its root infection rate is also higher than that of red clover (data not shown). As a result, large amounts of extraradical mycelium and spores can develop in the rhizosphere of maize. The size of the containers is also a factor determining fungal biomass production. In our experiments, the growth of both maize and red clover was likely to be limited by the size of the boxes.

The two AM fungal species used have very different morphology. G. mosseae develops an extensive external mycelium and produces few spores, while $G$. versiforme produces numerous spores and less mycelium. The results of the second experiment show that concentrations of nutrients and trace metals are much higher in $G$. mosseae than in $G$. versiforme. This indicates that these elements exist mainly in the mycelium and at lower concentrations in the spores. Spores are important propagules of AM fungi. They contain many nuclei (Cooke et al., 1987; Burggraaf and Beringer, 1989; Viera and Glenn, 1990) and large amounts of stored lipid and carbohydrate (Sward, 1981; Becard et al., 1991; Bonfante-Fasolo et al., 1994; Shachar-Hill et al., 1995). Further research is required to analyse mycelium and spores separately to determine their elemental composition. Li et al. (1992) have suggested that the nutrient concentrations in AMF spores should be adopted as a supplementary indicator for the classification and iden- tification of AM fungi. In their studies, Li et al. (1992) found that the percentages of $\mathrm{N}$ and $\mathrm{C}$ and their ratio in spores or sporocarps were variable among fungal species, but the difference between two genera was significant. More data are required before firm conclusions can be drawn. We cannot compare our data with hers because our samples were mixtures of spores and mycelium. The modified cultivation system could be used for research on this topic.

We found differences between host plant shoots and roots in nutrient concentrations, but the very high concentrations of $\mathrm{P}, \mathrm{Cu}$ and $\mathrm{Zn}$ found in fungal materials are of particular interest. The concentration of $\mathrm{Zn}$ in fungal material was about a factor of ten higher than in the host plants. This is very interesting because a number of studies have indicated that arbuscular mycorrhiza can protect the host plant from elevated concentrations of available $\mathrm{Zn}$ in the soil, and immobilisation of the metal in the fungus is one of the mechanisms that may be involved ( $\mathrm{Li}$ and Christie, this issue; Zhu et al., this issue). $\mathrm{Li}$ and Christie (this issue) found that when mycorrhizal red clover grew in soil amended with $\mathrm{Zn}$ there was less $\mathrm{Zn}$ in the soil solution compared with the growth of non-mycorrhizal plants and the mycorrhizal plants took up less $\mathrm{Zn}$ in the shoots and roots than nonmycorrhizal controls. The results of the present investigation lend support to the hypothesis that immobilisation of $\mathrm{Zn}$ in the fungal mycelium is one of the factors involved. 

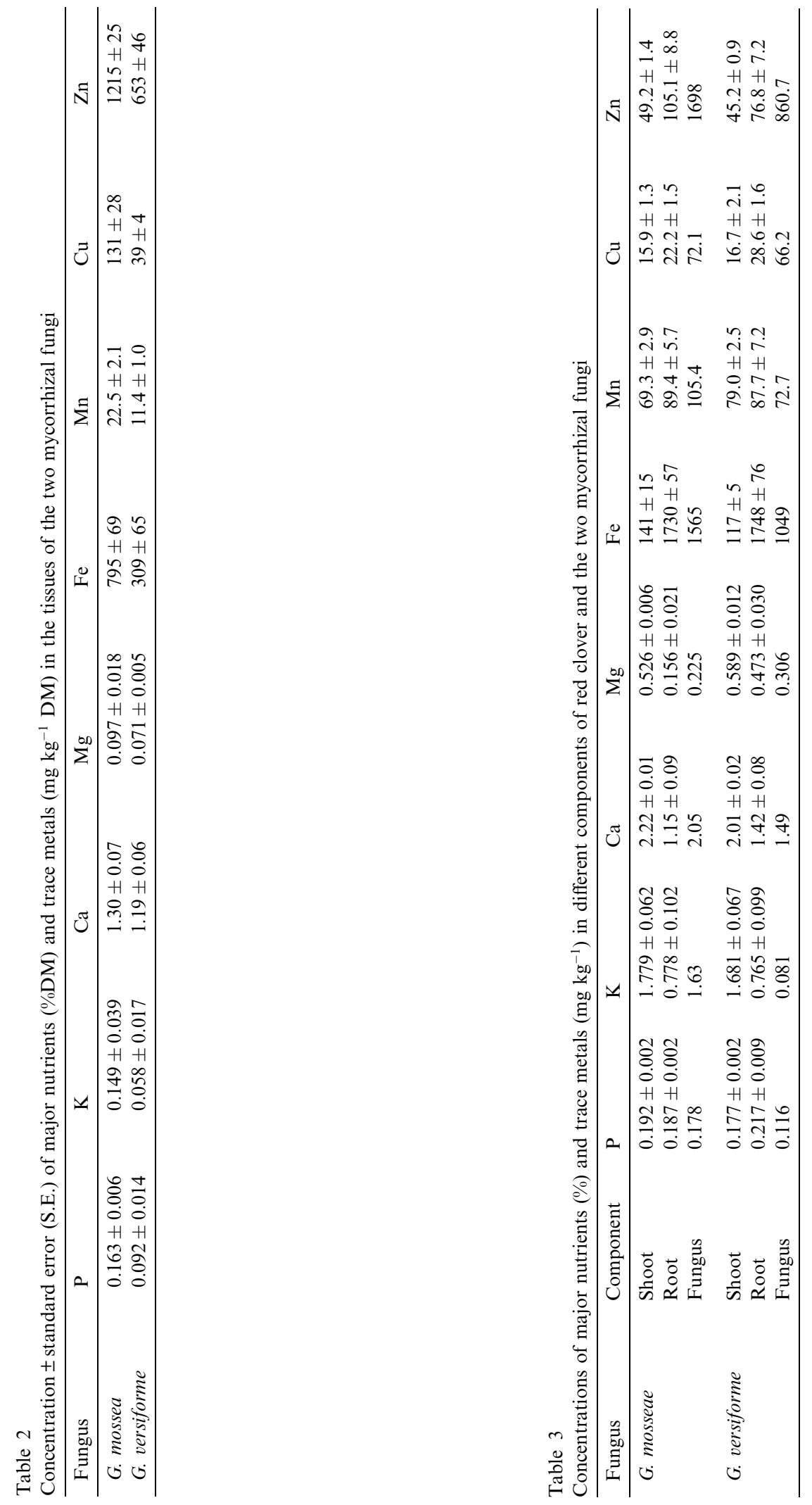
Much research has been conducted on the use of arbuscular mycorrhiza in the reclamation of mining sites and desert areas. Phosphorus deficiency and heavy metal toxicity are often important problems in these sites (Miller and Jastrow, 1992). Alleviation of $\mathrm{Zn}$ and $\mathrm{Cd}$ toxicity by arbuscular mycorrhiza has been reported by Dueck et al. (1986), Heggo et al. (1990), Weissenhorn et al. (1995) and Tao (1997). Turnau et al. (1993) have demonstrated greater accumulation of $\mathrm{Cd}, \mathrm{Ti}$ and $\mathrm{Ba}$ in fungal structures than in the host plant cells. According to Weissenhorn et al. (1994), prolonged exposure to Cd can result in the development of tolerance in Glomus species, but the mechanisms are still obscure. More work is needed on the potential role of arbuscular mycorrhiza in the phytoremediation of polluted soils and the modified glass bead compartment cultivation system may have a useful role to play in future studies.

\section{Acknowledgements}

We thank the Major State Basic Research Development Program of the People's Republic of China (Project G1999011807), The British Council and the Royal Society for providing financial support.

\section{References}

Becard, G., Doner, L.W., Rolin, D.B., Douds, D.D., Pfeffer, P.E., 1991. Identification and quantification of trehalose in vesicular-arbuscular mycorrhizal fungi by in vivo C-13 NMR and HPLC analyses. New Phytol. 118, 547-552.

Becard, G., Fortin, J.A., 1988. Early events of vesiculararbuscular mycorriza formation on Ri t-DNA transformed roots. New Phytol. 108, 211-218.

Becard, G., Piche, Y., 1989. Fungal growth stimulation by $\mathrm{CO}_{2}$ and root exudates in vesicular-arbuscular mycorrhizal symbiosis. Appl. Environ. Microbiol. 55, 2320-2325.

Becard, G., Piche, Y., 1992. Establishment of vesicular-arbuscular mycorrhiza in root organ culture: review and proposed methodology. Meth. Microbiol. 24, 89-108.

Bonfante-Fasolo, P., Balestrini, R., Mendgen, K., 1994. Storage and secretion processes in the spore of Gigaspora margarita Becker \& Hall as revealed by high-pressure freezing and freeze substitution. New Phytol. 128, 93-101.

Burggraaf, A.J.P., Beringer, J.E., 1989. Absence of nuclear DNA synthesis in vesicular-arbuscular mycorrhizal fungi during in vitro development. New Phytol. 111, 25-33.

Cooke, J.C., Jemma, J.N., Koske, R.E., 1987. Observations of nuclei in vesicular-arbuscular mycorrhizal fungi. Mycologia 79, 331-333.

Dueck, T.A., Visser, P., Ernst, W.H.O., 1986. Vesicular-arbuscular mycorrhizae decrease zinc toxicity to grasses growing in zinc-polluted soil. Soil Biol. Biochem. 18, 331-333.

Heggo, A., Angle, J.S., Chaney, R.L., 1990. Effects of vesiculararbuscular mycorrhizal fungi on heavy-metal uptake by soybeans. Soil Biol. Biochem. 22, 865-869.
Horn, K., Hahn, A., Pausch, F., Hock, B., 1993. Isolation of pure spore and hyphal fractions from vesicular-arbuscular mycorrhizal fungi. J. Plant Physiol. 141, 28-32.

Li, X.L., Cao, Y.P., 1993. Mechanisms of mineral nutrient uptake by VA mycorrhizae. Soils 25, 274-277.

Li, X.L., Christie, 2000. P. Changes in soil solution $\mathrm{Zn}$ and $\mathrm{pH}$ and uptake of $\mathrm{Zn}$ by arbuscular mycorrhizal red clover in Zn-contaminated soil. Chemosphere 42, 201-207.

Li, X.L., Marschner, H., George, E., 1991a. Acquisition of phosphorus and copper by VA mycorrhizal hyphae and root-to-shoot transport in white clover. Plant Soil 136, 49-57.

Li, X.L., Marschner, H., George, E., 1991b. Extension of the phosphorus depletion zone in VA-mycorrhizal white clover in a calcareous soil. Plant Soil 136, 41-48.

Li, X.L., Marschner, H., George, E., 1991c. Phosphorus depletion and $\mathrm{pH}$ decrease at the root-soil and hyphae-soil interfaces of VAM white clover fertilized with ammonium. New Phytol. 119, 397-404.

Li, H.Q., Wu, G.Y., Wang, H.G., Sheng, S.S., Jin, R.C., 1992. Preliminary study on elemental analysis of vesicular-arbuscular mycorrhizal fungi. Microbiology 19, 65-68.

Miller, R.M., Jastrow, J.D., 1992. The application of VA mycorrhizae to ecosystem restoration and reclamation. In: Allen, M.F. (Ed.), Mycorrhizal Functioning: An Integrative Plant-Fungal Process. Chapman \& Hall, New York, pp. 438-467.

Mugnier, J., Mosse, B., 1987. Spore germination and viability of a vesicular-arbuscular mycorrhizal fungus, Glomus mosseae. Trans. Br. Mycol. Soc. 88, 411-413.

Redecker, D., Thierfelder, H., Werner, D., 1995. A new cultivation system for arbuscular mycorrhizal fungi on glass beads. Angew. Bot. 69, 189-191.

Redecker, D., Thierfelder, H., Werner, D., 1998. Production of biomass of arbuscular mycorrhizal fungi in the glass bead compartment system. In: Varma, A. (Ed.), Mycorrhiza Manual. Springer, Berlin, pp. 495-498.

Rogers, J.B., Laidlaw, A.S., Christie, P., 2000. The role of arbuscular mycorrhizal fungi in the transfer of nutrients between white clover and perennial ryegrass. Chemosphere 42, 153-139.

Shachar-Hill, Y., Pfeffer, P.E., Douds, D.D., Osman, S.F., Doner, L.W., Ratcliffe, R.G., 1995. Partitioning of intermediary carbon metabolism in vesicular-arbuscular mycorrhizal leek. Plant Physiol. 108, 7-15.

Smith, S.E., Read, D.J., 1997. Mycorrhizal Symbiosis. second ed. Academic Press, London, pp. 127-160\Other-ref.

Sward, R.J., 1981. The structure of spores of Gigaspora margarita I. The dormant spore. New Phytol. 87, 761-768.

Tao, H.Q., 1997. Effect of arbuscular mycorrhiza on resistance of red clover to heavy metal $\mathrm{Zn}$ and $\mathrm{Cd}$ pollution. MS thesis, China Agricultural University, Beijing.

Turnau, K., Kottke, I., Oberwinkler, F., 1993. Element localization in mycorrhizal roots of Pteridium aquilinum (L.) Kuhn collected from experimental plots treated with cadmium dust. New Phytol. 123, 313-324.

Viera, A., Glenn, M.G., 1990. DNA content of vesiculararbuscular mycorrhizal fungal spores. Mycologia. 82, 263-267.

Weissenhorn, I., Glashoff, A., Leyval, C., Berthelin, J., 1994. Differential tolerance to $\mathrm{Cd}$ and $\mathrm{Zn}$ of arbuscular 
mycorrhizal (AM) fungal spores isolated from heavy metalpolluted and unpolluted soils. Plant Soil 167, 189-196.

Weissenhorn, I., Leyval, C., 1995. Root colonization of maize by a Cd-sensitive and a Cd-tolerant Glomus mosseae and Cadmium uptake in sand culture. Plant Soil 175, 233-238.
Williams, P.G., 1994. Axenic culture of arbuscular mycorrhizal fungi. In: Techniques for Mycorrhizal Research. Academic Press, London, pp. 527-536.

Zhu, Y.G., Christie, P., Laidlaw, A.S., 2000. Uptake of Zn by arbuscular mycorrhizal white clover from $\mathrm{Zn}$-contaminated soil. Chemosphere 42, 193-199. 